\title{
Human Resources Development In Yayasan Dana Sosial Al-Falah Surabaya On Islamic Economic Perspective
}

\author{
Soritua Ahmad Ramdani Harahap \\ University of Darussalam Gontor \\ E-mail: ramdaniharahap688@gmail.com
}

\begin{abstract}
Humans are resource of power in economic development that acts as the caliph of Allah on earth that is demanded to be responsible for the continuity of development that bring maslahah people in the world and the hereafter. However, in reality the human resource problem itself is still very complex, such as the lack of optimal quality of human resources, evidenced by the high number of unemployed in Indonesia. Where open unemployment in February 2017 reached 5,33\% from 5,50\% in February 2016. This phenomenon is interesting to review from the standpoint of human resource development in an Islamic perspective. By using qualitative methods and data collection through observation, interview and documentation of the Al-Falah Social Fund Foundation (YDSF) Surabaya as a sample of research. Finally this article explains that human resource development at Al-Falah Social Fund Foundation (YDSF) Surabaya uses spiritual and material approach. Through these two approaches, human resource development goes with programs aimed at improving human resources both spiritually and the material. In addition, this article also explains the obstacles encountered along with the solution to be applied by the Al-Falah Social Fund Foundation (YDSF) in order to optimize the quality of human resources.
\end{abstract}

Keywords : Islamic Economic Development, Human Resources Development, quality of human resources

\begin{abstract}
Abstrak
Manusia merupakan sumber daya kekuatan dalam pembangunan ekonomi yang berperan sebagai khalifah Allah di muka bumi, yaitu dituntut untuk bertanggungjawab atas kelangsungan pembangunan yang membawa maslahah umat di dunia dan akhirat. Akan tetapi dalam realitanya permasalahan SDM sendiri masih sangat kompleks, seperti belum optimalnya kualitas SDM, dibuktikan dengan tingginya jumlah pengangguran di Indonesia. Dimana pengangguran terbuka pada bulan Februari 2017 mencapai 5,33 \% dari 5,50 \% pada Februari 2016. Fenomena ini menarik untuk dikaji ulang dari sudut pandang pembangunan SDM dalam perspektif Islam. Dengan menggunakan metode kualitatif dan pengumpulan data melalui observasi, interview dan dokumentasi yaitu Yayasan Dana Sosial al Falah Surabaya sebagai sampel penelitian. Akhirnya artikel ini menjelaskan bahwa pembangunan sumber daya manusia di Yayasan Dana Sosial alFalah Surabaya menggunakan pendekatan spiritual dan material. Melalui dua pendekatan ini, pembangunan sumber daya manusia berjalan dengan program-program yang bertujuan untuk meningkatkan sumber daya manusia baik secara spiritual dan material. Selain itu, artikel ini juga menjelaskan kendala yang dihadapi beserta solusinya untuk diterapkan oleh Yayasan Dana Sosial al Falah Surabaya dalam rangka untuk mengoptimalkan kualitas SDM.
\end{abstract}


Kata Kunci: Ekonomi Pembangunan Islam, Pembangunan Sumber daya manusia, kualitas sumber daya manusia

\section{Introduction}

Islam is a perfect religion. It contains complete rules in all aspects of human life including the economy. Islam asks all Muslims to increase and to develop in all aspects of life including the economy and finance aspect. Therefore, the economic concept based on Qur'an and al-Sunnah in Islam as well as the Islamic economic development concept. In addition, this basic concept as different as the conventional economic development that put forward by western economic thinking. (Dimyati, 2017, 154)

One aspect of the Islamic economic development is human resources. The effectiveness of an organization depends on human resources accordance to their duties and responsibilities in managing the resources that exist within the organization. (Imron Buyung, 2008, 8) According to data of The Central Bureau of Statistics (BPS) noted that open unemployment data by province in Indonesia has increased, seen from February of 5,50 percent rising to 5,61 in August 2016. In February 2017 it amounted to 5,33 percent to 5,50. These data described an significant increasing in unemployment. Thus, the effectiveness of human resources must be based on the principle of Islamic values for the realization of the caliphs that provide benefits in each institutional, community and country. Therefore, Islamic human resources development must be in line with the concept of Islamic economic development.

Islam is very concerned to the effectiveness of human resources by make human as a caliph on earth in managing natural resources, which already exists. Thus, the human resources is a vital part of the important role as planner and active players in every activity of the organization. Without qualified human resources, an organization cannot run their activity well. Therefore, human resources should be managed well. It described in the holy Qur'an about the role of human as the Caliph in al-baqarah verse 30 .

The human resources is the largest power in the management of all of resources in advance of the earth, because basically all of Allah's creation deliberately created for all mankind. (Nurul Huda, 2015, 182) Therefore, the Humans as a user of natural resources obligated to maintain, develop, and utilize it well. Accordingly, when a country possesses an excess of natural resources, it is not necessarily be a prosperous people if they do not have the ability to utilize of the human resources. On the contrary, even the country that lack natural resources but can utilize the human resources, they can prosperous people. (Ratonggi Siregar, 2017, 378)

In this era of modernization needed the institutions that contribute in developing human resources. However, most of these human resources development institutions tend to grow stagnant and even backward due to lack of public trust to this institution and affected to the development of human resource and financial organization. (Djaelany, 2014, 63) Different institutions with of Al-Falah Social Fund Foundation (YDSF) Surabaya that was established on March 1, 1987. This institution focused on improving and empowering the quality of human and community resources by da'wah Islamiyah. In addition, this institution is one of the institutions that is trusted credibly by the community, so with this reputation can fulfill their institutional funding.

Furthermore, this institution can survive and provide many benefits started 
since the establishment of this institution to date. Currently, this institution has benefited in 34 provinces in Indonesia especially in the distribution of infaq, zakat and alms funds. The vision and the mission of achievement of of Al-Falah Social Fund Foundation (YDSF) Surabaya as a professional and trusted institution in utilization of charity fund in management of zakat, infaq in Indonesia. (http://www.ydsf.org)

Based on these problems in human resource development, it is necessary to get an answer about how the application or implementation of Islamic economic development in empowering human resources. Therefore, the researcher intend to examine the development of human resources at the YDSF institution Surabaya as one of the institutions that implement the development of Islamic economics, especially human resources. Hopefully, this research can help and solve the problems of development, especially related to the development of human resources and its constraints and solutions.

The type of this research is qualitative descriptive research (qualitative descriptive research). According to Nasution explained about qualitative research, there is no choice but to make man as the main research instrument. The reason for this is due to the similarity of all its shape. (Sugiyono, 2014, 399) Research focus issued, procedures research, and the hypothesis used, even the expected outcome of these things cannot be determined in a certain and clear previously. Thus, all things still need to be developed in research related to certain circumstances and not sure. So there is no other choice and only researchers himself as the only one who can achieve it.

Researcher choose qualitative research, because it has determined the focus of the research is clear and definite. In meet the completeness of data, researcher make observations field and do the interview. After the observation and interview, continued with the documentation available data. To find the best results and researchers will use triangulation method to facilitate the writing of the conclusion.

In the selection of this sample, the sample obtained did not represent the entire population because the sampling was not random, but determined directly in accordance with the terms and objectives of the study that is using purposive sampling technique. Purposive sampling aims to determine the sample intentionally, where the selected class has the same initial ability not based on the same random, level or religion. (Nurul Hanifah, 2016, 69)

And so on, so the number of samples more and more. In this study, researcher also used structured interviews. Structured interview was used as data collection techniques, if the data researcher already know for certain information to be obtained. In this research, researcher have selected 5 sample people to obtain information through interviews conducted, they are: (1) Deputy Director of YDSF, (2) Head of Human Resources, (3) Asset Purchasing Staff, (4) Donor Service Staff (LD), and (5) Mosque Program Staff (Field of Da'wah).

\section{Definition of Islamic Economic Development}

In terms of development comes from waking words; rise, consisting of derivation word from wake up that is build or development which means to build, make, establish, repair; making it go forward and expand. (Syamsuri, 2018, 75) In modern arabic terms development according to Wan Mohd Nor Wan Daud is derived from the sentence تنمية (Tanmiyyah) which intends growth; and also تقدم which means forward or progress. 
However, the term development when referring to the words of Allah swt in Alqur'an actually comes from the sentence

عمر ('Amara) which means life, like a phrase عمر الرجل عمر gives the sense of someone living in a long time. As the word of Allah swt is contained in the verse Hud verse 61.

Islamic economic development also has its own philosophy, concepts, theories, and epistemology that are different from western development theories and some models. Therefore, Islamic economic development demands and makes man to a balance between happiness in the world and in hereafter, justice between individual and community rights, fostering a harmony between individuals and society, preserving natural conservation of damage from without distinguishing between spirituality and factors physical. (Syamsuri, 2018, 80) By this explain, islam clearly stipulates how his people should be able to do an activity based on primary sources of Muslims as Al-Qur'an and hadith. With the main grip above, it is expected that humans can be a combination of factors of spirituality and physical factors earlier.

In the midst of the failure development practices that are based on the system of world capitalism emerged an alternative economic system based on the values of teachings Islamic Shari'a. At the time of monetary crisis hit the world economy, economic institutions in development countries that implement shari'a mechanism proven to survive and even some of them be able to grow and thrive. (Agung Eko, 2013, 5) In some economic theories, values offered Islamic economy relatively new thing. Although in fact Islamic teachings provide clues in economic activity has begun from the time of the apostles, but the building science still requires a variety of processes to become established and appropriate to applicated.

Epistemological development according to Nor Wan Daud in the perspective of Islam is the increase of human consciousness of its responsibility to the nature and the case of the sequence of the legitimate virtues, charity sincere, wise, brave, simple and fair deeds. This development can be measured by four main issues of freedom, justice, morals, and happiness. (Syamsuri, 2016, 214) Essence development carried out by a country in economic view of Islam must have a distant goal, which is the improvement of human prosperity and happiness in the world and the hereafter. Development should not be only for the benefit of the material alone but must also be connected with a more enduring is hereafter. Therefore, development must refer to or based on the provisions in Islamic Shari'ah both written in the Qur'an, hadith, ijma, qiyas, and ijtihad the scholars of fiqh.

Islam the development of human resources in full has become the first target in view of Islamic economics. In addition, development is not only limited to build people's economy alone, but rather to one's mental development. Development according to Islam is not just to fulfill the physical needs of every individual alone, but rather to be connected to spiritual needs as well. Spiritual needs built by istiqomah and routine can automatically encourage the independence, awareness of each individual person to be able to build himself, and build the nation and all humanity.

\section{Principles of Human Resources}

Development of economics in Islam is multi-dimensional (various dimensions) namely balanced development of materiality and spirituality, quantitative and qualitative, internal and external. (Almizan, 2016, 
2017) Among the principles of Islamic social life dynamics are putting particular emphasis on the two cases: First, the optimal use of resources provided by Allah SWT to humans. Second, the use of resources and human relations fairly on the basis of rights and justice.

Islamic economic perspectives of economic growth, there are several factors that will affect the growth itself, these factors there are four, including:

1. Natural resources. Economic growth desperately needs resources that can be used in producing some physical assets to generate income. (Irfan Syauqi, 2016, 142) Physical aspects include plants, industry, machinery, and so on.

2. Human resources. Another important determinant is human resources. Humans are the most active role in economic growth. Their role includes several fields, such as the exploitation of existing natural resources, capital accumulation, and developing socioeconomic and political institutions of society.

3. Entrepreneurship. Entrepreneurship is key in the process of economic growth and very stable. Entrepreneurs are considered to have a much needed dynamic function in an economic growth.

4. Technology. Economists claim that technological progress is a source of economic growth is the most important. Economic growth is considered not to follow the historical process in general, does not happen constantly in a state that can not be determined.

While the innovation process is the use of new techniques that are cheaper to produce an existing product. The Qur'an commands to search and study pretty much in the Qur'an. In economic terms, could be changes in technology. In the Qur'an there is also a command to explore what is on earth for the welfare of man. Therefore, innovation becomes a necessity that needs to be designed seriously by the government. Islam is a religious teaching that commands its people to always be innovative. Islam does not challenge the concept of technological change as described above, even in reality Islam supports technological progress.

\section{Human Resources Development in Islamic Economics}

Islam is a religion that contains effort, struggle and movement towards social change. (Nur Chamid, 2010, 333) The elements in Islam lead to healthy social change desired in Islamic sharia. That task includes the terms or elements of leadership, economic, intellectual and political Islam are high. The purpose of all this is to formulate direction and strategy and how to achieve it. At the same time build the institutions and processes that can be used to design subsequent policies. That is part of the issue of thinking in order to Islamize development. There are several ways in the human resources development process consists of 5 steps as follows (Moekijat, 1997, 67): (1) Designing human resource requirements that will come. (2) Projecting the upcoming human resources inventory. (3) Compare needs designed with projected inventory. (4) Planning for policies and programs to meet all the needs for human resources. (5) Assessing the effectiveness of human resource development.

In another explanation, Hadari Nawawi stated that human resources personnel development program covers a wide enough aspect such as an improvement of work ability, improvement of dedication, morale and work discipline as well as direction and formation of objective work motif. Development of human resources personnel can be reached through various ways. (Hadari Nawawi, 1997, 67) One of them is through training activities. Through training activities, human 
resources can be utilized by the organization as much as possible.

Human resources is a translation of the English language that is human resources but there are some experts or experts who equate human resources as labor. (Edy Sutrisno, 2009, 4) In addition there are some people who are equated with the manpower that the understanding of human resources with personal. Meanwhile, according to Abdurrahmat Fatoni states a separate meaning into 4 syllables namely management, resources, and power of human. (Abdurrahmat Fatoni, 2006, 10) Human resources that make man as an optimal resource in a development.

The basis of Islamic philosophy of economics states that the function of human resources both in the context of individuals or members of society is as khalifah Allah on earth. This excess Islamic concept of development of other concepts, by subjecting the human role in the highest place and very honored, but also have a responsibility to each charity. Human resources is the representative of God on earth for the prosperity of the earth and are accountable to God about the management of resources have been entrusted to him.

One of the systems in which development is based on Islam is the use of development for humans, not human beings for development, is to make the dynamics of Islamic human beings retain their status as God's khalifah on earth: among them know the secrets of his life, know the journey of his life, know the purpose of his life and know the place eternal. Although Islam gives a deep concern for the problem of economic development, but as human beings with human status of Islamic sebegini, economic development is only part of the whole human development.

Human Resources, both on aspects of quality and quantity is very necessary to be able to determine a person's performance, productivity and success of an institution. Islamic banking as an institution for businesses based values and principles of sharia, qualification and quality of human resources is clearly more demanded the integration between "knowledge, skill dan ability" (KSA) with moral commitment and personal integrity, there are 5 things that need to be held for all human resources, among them (Mohammad Ghozali, 2018, 169):

1. Shidiq: Having honesty and always underlying the words of belief, and deeds based on the teachings of Islam.

2. Istiqomah: Consistent with the faith and values that are good in spite of the challenges and temptations.

3. Fatonah : Understand and deeply appreciate all tasks and duties.

4. Amanah : Have responsibility to perform obligations.

5. Tabligh: Inviting well as uswah.

In view of Islam there are some basic concepts to be considered. Fundamentals of Islamic philosophy to the natural approach to such development, is as follows (Syamsuri, 2018, 151):

1. Tauhid has the meaning of God's oneness as the creator of the universe and all its contents, while the way to its impression by performing worship is only to God alone. Tauhid established laws regarding the relationship between God and man and between man and fellow man.

2. Rububiyyah has a meaning by hammering God in creation, giving sustenance, maintaining the universe of its destruction, lifting and the raising of original human being is an application of rububiyyah belief. Rububiyyah nature also contains the intention to guidance throughout what God created to happiness in the world and the hereafter.

3. 'Adalah outline is a situation where every human being receives equal 
perlakuaan before the law, equal rights, the right to a decent life, the right to enjoy development and the absence of the parties fared less well even balance in every aspect of life.

4. Caliph, which refers to the role of man as God's chaliph on earth. It defines the status and role of human beings, and determine human responsibility as a Muslim and as a Muslim ummah. Responsibility as a perfect man in the form of behavior between man and his Lord, people always side by side with its natural surroundings.

5. Tazkiyah epistemologically means a hygiene and treatment have methods and techniques, nature of Shari'a, and its impact on behavior and efforts to seek the pleasure of Allah. Through this tazkiyyah concept of man can develop himself who finally awakens all the dimensions of life including economic dimension and can prosper in this world and the hereafter.

Human capital can be a reliable human resource in development if the quality is high. In this case, human resources development has an important role in relation to improve the quality of development and to maintain the continuity of development itself. Meanwhile, the education system has failed to bear materiaslistik proven human resource output was once in charge of science and technology and competitiveness. (Sugeng Kurniawan, 2015,2 ) There is a very strong impression that the development of the living sciences is something that is in a valuefree region, so completely untouched by the value of religion.

Therefore, Islam is present as a religion as well as a simple life view that rahmatan lil 'alamin, clearly not familiar with the concept of separation between ritual affairs and worldly affairs. (M. Makmun Rasyid, 2016, 94) Prayer is worship that is part of the Shari'a where all Muslims must be bound as the attachment of the Muslims to the Shari'a in other fields, such as economy, and social politics. Because, the whole activity of a Muslim is a worship that aims to achieve the happiness of the world and the hereafter (falah).

\section{Constraint and Solution in Human Resource Development}

In the coming era, human laborers face a formidable challenge. The development of science and technology is very rapid and man is required to have a certain specialization, and each specialization only knows himself deeply but not knowing much about things outside himself. Man is increasingly fragmented by the technical rules that bind him, so impersonal social relationships are increasingly implicated. In the end, science and technology will replace the position and role of human beings as workers and individuals intact, because the work of human routine done by machines that work is considered more thorough, more effective, efficient, and more daring. (Sri Agustin, 2010, 59)

As we know, the Islamic personality will only be felt from the combination than the mindset and attitude patterns slam. Here, the individual with the personality of Islam acquires a special meaning, understands and makes decisions about a matter and deed in accordance with the law of the Shari'a, so that he is able to extract existing laws, know lawful and haram, have consciousness and mature thinking, strong and precise reason, and able to analyze the various acts with true conformity with the parameters of sharia law. Then, the individual concerned can produce deeds and behaviors to meet the demands of his instincts and physical necessities based on the teachings of Islam.

Four things are also included in the assessment of human resources in doing 
its work, there are several assessment of Islamic human resource performance is one of the things that give a big influence on the development of society, especially in which there is culture and social values (Social values). (Moekijat, 1991, 56) The influence of the values that exist in the community is the belief and values that are dominant from the wider community, such as individual freedom, collectivism, politeness, cleanliness and so forth. Sharia management is supposed to be based on things that are syar'i. Adiwarman A. Karim stated that shari'a management should cover four things, as follows (Burhanuddin Yusuf, 2016, 49) :

1. Islamic management must be based on Islamic values and morals, such as tauhid, justice, siddiq, amanah, fathanah, and tabligh. The above values are the qualities that Muslims must apply.

2. Compensation and emphasis on the fulfillment of basic needs of workers.

3. Humanitarian and spiritual factors, which workers must be treated with respect and participate in decisionmaking.

4. System and organizational structure (Ukhuwah Islamiyah), where the leader should be close to subordinates. Proximity leaders and subordinates in ukhuwah Islamiyah, this will not eliminate the formal authority and obedience of subordinates to superiors for closeness was not sinful.

\section{Profile of Al-Falah Social Fund Foundation (YDSF) Surabaya}

YDSF Surabaya is one of the National Institute of Amil Zakat (LAZNAS) which was established on March 1, 1987 by prominent figures, scholars, and Muslim businessmen. This foundation obtained the legality based on the Decree of the Minister of Religious Affairs no. 532 in 2001. (http://www.ydsf.org) Starting from alFalah Mosque Surabaya that is a milestone in the founding of this foundation, therefore the movement of this foundation cannot be separated from al-Falah mosque. From there the national amil zakat institute (LAZNAS) was started. (Magazine Al-falah, 14)

According to Farid Jahja (a member of the YDSF Board of Trustees), the establishment of YDSF stemmed from Abdul Karim's unique habit as chair of the al-Falah mosque foundation at that times. Abdul Karim's habit was the traveling around Surabaya to find a mosque or mushalla that deserving help. If there is a mosque or mushalla neglected its construction, then Mr. Karim contacted his business colleagues and some Muslim journalists who he knew to be invited together in an effort to find a solution for the construction of mosques or mushalla can be resolved. Starting from this habit arose the idea to accommodate these deeds in a worthy institution. This situation is very different than in 2012, this institution has been widely known by the people of Surabaya and even abroad. Currently, the foundation has 277,984 donors and 6 branch offices. (Magazine Al-Falah, 2018, 1)

\section{Human Resource Development In YDSF Surabaya}

Epistemologically development by Nor Wan Daud in Islamic perspective is to increase awareness of a man of his responsibility towards essence and doings are done legitimated, sincere deeds, wisdom, bold, simple and fair. This development can be measured by four main issues of freedom, justice, moral and happines. Human beings become important subject in creating existing development with their own natural resources.

Qualified employment recruitment has an important role in realizing qualified new human resources in YDSF Surabaya. This is reflected in every 
division of YDSF Surabaya in eliminating every new human resources recruitment in accordance with recruitment standardization of human resource. Khursid Ahmad confirmed this, that four important factors that affect economic growth include natural resources, human resources, technology, and entrepreneurship. One of the important factors above is the human resources factor. In the researcher's observation, employment recruitment in YDSF concerns the quality of recruitment through the examination process and deliberation to adapt to the fulfillment of human resources in each division.

Based on the interview above that qualified human resources in employment recruitment is very concerned about various important things. The employment recruitment is the most important attention in YDSF Surabaya that is based on special requirement, such as:

1. Good in reciting the Qur'an. This is an obligation requirement because YDSF is an Islamic institution that is engaged in da'wah and unlikely to receive human resources who are bad in reciting the al-Qur'an.

2. Interview. It aimed to know about the personal and character of each employment candidate, it is necessary to have an interview based on questions that have been prepared by the human resources division.

3. Self-skill, where all applicants who come to YDSF will be examined about their expertise, for example: there are applicants who have expertise in the journalism, the examination related this field, financial and so forth.

This form of optimization mechanism is in accordance with aspects of human resource development in Islamic development economics. It was explained by Mohammad Ghozali about quality human resources must have five characteristics, namely; shidiq, istiqomah, fatonah, amanah, and tabligh. In this case, YDSF Surabaya emphasizes the characteristic of the trust (amanah) which is one of the foundations of human resource development. Currently the employment assignment in some divisions and sections in YDSF Surabaya is described of human resource optimization form. The total number of employment at YDSF is 118 people.

Data from total number of employment a YDSF Surabaya have reflected the work structure efficiency in collecting and distributing the funds of the ummah for the sake of da'wah Islamiyah Therefore YDSF always strives to the best possible to give the best in da'wah progress through the economic field. Although YDSF has not too much employment but YSDF can implement various programs without feeling lack of personal, eventually YDSF Surabaya gained widely public trust on this institution.

The implementation of various programs in YDSF Surabaya must be intended and devoted to worship (ibadah). In Islam, all work must be based on the concept of worship, it is not permissible for a Muslim to separate the secret (ukhrawi) matter and profane matter (dunyawi). All activities must be in accordance with Islamic Sharia's and worth of worship. In this case, researcher divides the development of human resources in YDSF based on 2 approaches are spiritual and material approaches.

\section{Human Resource Development based on Spiritual Approach}

The spiritual approach is the basic value and meaning that underlies one's life both ukhrawi and dunyawi. A Muslim who has a good spirituality will show good behavior as well. Given the manifestation of good manners, a Muslim will interpret life as a sacred, where all that is aimed solely for worship. (Mohammad Arief, 2010, 187) Human resources development 
in YDSF according to spiritual approach, including:

1. Workshops program

In building a good spiritual atmosphere, the Human Resources Division has two study programs or workshops for employment and donors. Employment's workshop conducted weekly, while donor's workshop conducted only once a month. A workshop program that has been launched is used by every employment to be deeply deepen the various issues related to daily life or other sunnah worship.

Table. 1.1 Workshop Schedule

\begin{tabular}{|c|l|l|}
\hline TIME & $\begin{array}{l}\text { THE } \\
\text { PREACHER }\end{array}$ & \multicolumn{1}{c|}{ TOPIC } \\
\hline $\begin{array}{c}\text { WEEK } \\
\text { I }\end{array}$ & $\begin{array}{l}\text { UST. } \\
\text { AGUNG } \\
\text { CAHYADI }\end{array}$ & $\begin{array}{l}\text { ACCORDING } \\
\text { TO AL-FIQH }\end{array}$ \\
\hline $\begin{array}{c}\text { WEEK } \\
\text { II }\end{array}$ & $\begin{array}{l}\text { UST. } \\
\text { BANGUN } \\
\text { SAMUDRA }\end{array}$ & $\begin{array}{l}\text { ACCORDING } \\
\text { TO TAUHID }\end{array}$ \\
\hline $\begin{array}{c}\text { WEEK } \\
\text { III }\end{array}$ & $\begin{array}{l}\text { UST. } \\
\text { NAROTAM }\end{array}$ & $\begin{array}{l}\text { EMPLOYMENT } \\
\text { DEVELOPMEN } \\
\text { T WORKSHOP }\end{array}$ \\
\hline $\begin{array}{c}\text { WEEK } \\
\text { IV }\end{array}$ & $\begin{array}{l}\text { UST. } \\
\text { JUNAEDI }\end{array}$ & $\begin{array}{l}\text { ACCORDING } \\
\text { TO THEMATIC }\end{array}$ \\
\hline
\end{tabular}

The table above explains the importance of applying spiritual aspect in human resource development. Through these workshops, hoped that it will be able to inculcate the worth of tauhid and the adequate understanding of the religion. Thus, the topics of the workshop must related to the basic of the philosophy and basis of Islam in human development, through tauhid, Rububiyyah, 'is, khilfah, and tazkiyah. Therefore, this relationship will empower human resources based on the potentials of each individual, such as:

a. Body potential, human potential related to the ability and technical skills b. Heart potential, human potential relates to the ability of moral, aesthetic, ethical, faithful, and have a sense of self over divine greatness.

c. Reason potential, human potential related to the ability to develop science and technology.

d. The potential of life, human potential related to the ability to adapt to the environment, sustain life, and face challenges.

\section{Program of Reciting al-Qur'an Together}

In addition to the workshop program, the human resources division also launched a program of reciting alQur'an together in building a spiritual aspect for human resource development in YDSF. Through this program, all employment can improve mutually their reciting of al-Quran for better. This program is also intended to be the power of all human resources when will carry out its activities.

Table. 1.2 Reciting Al-Qur'an Schedule

\begin{tabular}{|c|c|c|}
\hline TIME & DAY & AGENDA \\
\hline \multirow[t]{2}{*}{$\begin{array}{c}\text { WEEK } \\
\text { I } \\
\end{array}$} & WEDNESDAY & $\begin{array}{l}\text { TILAWAH } \\
\text { YASIN }\end{array}$ \\
\hline & FRIDAY & $\begin{array}{l}\text { TILAWAH } \\
\text { AL-KAHFI }\end{array}$ \\
\hline \multirow[t]{2}{*}{$\begin{array}{c}\text { WEEK } \\
\text { II }\end{array}$} & WEDNESDAY & $\begin{array}{l}\text { TILAWAH } \\
\text { YASIN }\end{array}$ \\
\hline & FRIDAY & $\begin{array}{l}\text { TILAWAH } \\
\text { AL-KAHFI }\end{array}$ \\
\hline \multirow[t]{2}{*}{$\begin{array}{c}\text { WEEK } \\
\text { III } \\
\end{array}$} & WEDNESDAY & $\begin{array}{l}\text { TILAWAH } \\
\text { YASIN }\end{array}$ \\
\hline & FRIDAY & $\begin{array}{l}\text { TILAWAH } \\
\text { AL-KAHFI }\end{array}$ \\
\hline \multirow[t]{2}{*}{$\begin{array}{c}\text { WEEK } \\
\text { IV } \\
\end{array}$} & WEDNESDAY & $\begin{array}{l}\text { TILAWAH } \\
\text { YASIN }\end{array}$ \\
\hline & FRIDAY & $\begin{array}{l}\text { TILAWAH } \\
\text { AL-KAHFI }\end{array}$ \\
\hline
\end{tabular}

The purpose of human resource development in YDSF through spiritual approach is expected to understand the essence of work. In addition to the 
spiritual approach, YDSF also develops human resources through material approaches, as a trigger for the professionalism of human resource development.

\section{Human Resource Development through Material Approach}

Human resource in YDSF through material approach, such as:

1. Human Resource Welfare Program

This program is aimed for fulfilling the prosperity of every human resource in YDSF Surabaya. The fulfillment of this welfare refers to the ability of the institution to fulfill welfare and to hire every employment even though the salary does not conform to government salary standards. Thus, the researcher concludes that YDSF Surabaya is very concerned about the needs of the fulfillment of every employment welfare. Although, this concern has not been enough to satisfy all of its employment welfare but it is enough to provide every employment about comfort and enthusiasm to work and charity.

\section{Self-Development Program}

Self-development training programs are also one of the most important aspects. There are various training programs implemented at YDSF, such as:

a. On-the-job training, this training is aimed to realize understanding and introduction of YDSF in depth for new employment.

b. Motivation training which is organized to be able to build every human resources confidence, that is how to communicate well with fellow and his boss. This training is the basic training that must be followed by every employment.

c. Specialized journalistic training is aimed for the publication and media divisions in order to develop their division. d. Fundraising training which is aimed for improving employment capability in fundraising activities of zakah, alms and infaq funds. Therefore, the distribution of fundraising activities should be balanced with fundraising activities, especially now there are many zakat institutions that implement training such as YDSF.

The researcher concludes that conducting of various developments is one of ways in creating of human resources that truly understand and realize the vision and mission of YDSF Surabaya. In addition, through this training materialized to build the professional and moral human resources. The effort for building the professional and moral human resource development must be based on the values of Islamic teachings. One of them, if everyone is grateful for the blessings God gives, then God will add him even greater favors. This value provides the motivation of every employment to always work, to try and to be grateful for his work. (Ima Amaliah, 2013, 166) Thus, the form of human resource development is formed from the attitude and view of every Muslim in dealing with every action with a positive work attitude.

YDSF builders and managers always initiate a positive perspective and work attitude. This guiding is more intended to explain that YDSF is a place of charity and da'wah rather it is not a place to find livehood. These positive escorts and guiding trigger every available human resource to always contribute and take the initiative to advance this institution. Therefore the implementation of human resource development provides the ideal form of human resources.

YDSF Surabaya also consider another aspects that must be owned by every employment, those are attitude, skill and knowledge. The attitude aspects that are preferred among the three, while 
the skills and knowledge can be developed in line with the implementation of programs that have been proclaimed. Attitude aspect can be seen in various assignments given to each employment. This assignment answers how employment is trustworthy in carrying out the given task. The trustworthy of employment is also driven by the division of human resources in creating a good administrative system so as not to give any chance for doing fraud. For example, as an institution that manages community funds, YDSF management is not easy to approve the budget. Outgoing budget must be in accordance with the existing procedural, initiated the submission of programs and activities by the staff then submitted to the manager and approved by the head of division and the Director of the institution, even the final submission of this budget after submitted back to the board.

\section{Increased Work Ethics of Human Resources}

Besides the development aspects above, some aspects that should also be improved are the work ethic of human resources. The improvement of work ethic is deliberately formed with a gradual form of assignment, starting with small, medium to large and subsequent judgment. Therefore, there are several ways in improving the work ethic of human resources in YSDF, including:

1. The basic assignment for each interpersonal YDSF. This assignment is based on the job description provided by the manager and the head of the division. This assignment is obligated to do for every head of division as a form of qudwah in the execution of this assignment, and subsequently maintaining the harmonization of work among the sections.

2. Assignment by work achievement target. This assignment adjusts to the employment capability and this assignment involves the head of the division to control the execution of tasks so that the targets materialized as expected.

3. Assignment by discipline. Discipline in every job makes all the work done well and on time.

4. Additional assignments. This assignment is more directed to the agenda of togetherness such as inspriring day. This togetherness agenda is familial, it making easier to being suggested by every division and part for the progress of this institution.

The physical and mental development of human resources as described previously is encouraged by the existence of justice in the policies and disciplinary rules of YDSF. Moreover, YDSF as a fund management institution of ummah, it is absolutely discipline and justice in every policy made.

According the prior describing, researcher concludes that YDSF has built human resources in accordance with the basic concept of Islamic development economy that meets aspects of quality, professional and moral. One of the goals of developing human resources in Islam can provide benefits to others and the surrounding environment and can optimize every tasked job. In the hope that all assigned should be done with sincerity and only expect a reply from God.

\section{Constraint and Solution of Human Resource Development at YDSF \\ Every human resource} development process always has constraint. The YDSF obstacles are in:

1. Inadequate aspects of recruitment for newly trained employment. In this case, it is specifically related to the skill and experience aspects of the employment that the human resources division must really think hard to develop new human resource quality. 
2. Yet is lack of employment education quality that is still far from expected. This affected to the improvement of self-employment quality. This influence occurred because they have not gained self-possessing qualities in their previous education. Therefore, the Human Resource division requires all new employment to explore their assignment parts in YDSF and it resolved by required of providing various training, comparative study to other institutions.

3. Less of optimality time toward proclaimed implementation of program. This affected to the late completion of the program beyond the scheduled time. Therefore, for solution, every human resources that must be able to streamline their time in completing the existing program.

4. The main constraint is the aged 40-50 years employment more dominant than those aged under $30-40$ years so that YDSF less developed than other institutions. Therefore, aged 40-50 years employment are required to improve the quality of work in accordance with the development of the current era. In addition, the solution with the development of human resources (development of personnel) as one element to meet the basic skills ability (ability to work) to achieve job performance. It is aimed at the ultimate goal of optimal empowerment of human resources with the right people, the right position and on time. And also by Engaging younger generations in every employment recruitment at YDSF.

Beside some exposure above, YDSF also requires the existence of SOP in every part. For example: the fundraising section, this section is provided with a book of receipts that have been printed at the office to note every fund. Their assignment are collecting and depositing the funding to the bank. Thus, all payment activities will be recorded. This system aimed for being spared from manipulating data in the field. This application is known as the "WasKat" as a system, which has meaning to supervise all administration practice.

In the analysis of the researcher, the solution given in solving the above problems in accordance with the existing problems. Of the four problems above, all human resources are expected to be able to make a challenge into an opportunity and the second is to turn it into a good mental attitude.

\section{Conclusion}

Finally, the researcher concluded that YDSF Surabaya institution implemented the concept of Islamic economic development in the effectiveness of human resources within the institution. The implementation of the concept of Islamic economic development in the effectiveness of human resources and its constraints and solutions, namely the implementation of human resource development at YDSF Surabaya uses two approaches, namely spiritual and material approach. These two approaches work well with the programs. Therefore, YDSF Surabaya can survive to this day by combining material and spiritual development in every program and its implementation so that many get support and trust from public. The main obstacle is the more dominant employment age 4050 years than those aged under 30-40 years so that YDSF Surabaya less developed than other institutions. The solution with the development of human resources (development of personnel) as one element to meet the basic skills ability (ability to work) to achieve job performance. In addition, YDSF Surabaya must also play a young human resource in every program. With the role they are expected to be able to create programs that can attract the hearts of muzakki for the spirit in issuing zakat, infaq, and 
shadaqoh funds entrusted to YDSF Surabaya. With the combination of the young and the old will be able to create a

\section{BIBLIOGRAPHY}

Al-mizan. 2016. Pembangunan Ekonomi Dalam Perspektif Ekonomi Islam. Maqdis: Jurnal kajian ekonomi islamvolume 1, No. 2 Juli-Desember.

Agustin, Sri. 2010. Tantangan Pengembangan Sumber Daya Manusia Indonesia Di Era Global, Jurnal Jurusan Pendidikan Geografi Fis Uny.

Amaliah, Ima. 2013. Pengaruh Nilai Islam Terhadap Kinerja Kerja, Jurnal MIMBAR, Vol. 29, No. 2 Desember.

Arief, Mohammad. 2010. Spiritual Manajemen: Sebuah Refleksi Dari Pengembangan Ilmu Manajemen, Jurnal Ekonomi Modernisasi, volume 6 Nomor Juni.

Asmuni. 2003. Konsep Pembangunan Ekonomi Islam, Jurnal Al-Mawaridi, Edisi X.

Asnaini. 2008. Pengembangan Mutu SDM Perbankan Syari'ah: Sebagai Upaya Pengembangan Ekonomi Islam, Jurnal La_Riba, vol.II, No.l, Juli.

Beik, Irfan Syauqi. 2016. Ekonomi Pembangunan Syariah, Jakarta: PT raja Grafindo.

Buyung, Imron. 2008. Strategi Pengembangan Sumber Daya Manusia Di Pondok Pesantren Bahrul Ulum Tambak Beras Jombang Jawa Timur, (Yogyakarta: Fakultas Dakwah Universitas Islam Negeri Sunan Kalijaga Yogyakarta). strong synergy in creating and delivering programs to the community.

Chamid, Nur, MM. 2010. Sejarah Pemikiran Ekonomi Islam, Yogyakarta: Pustaka Pelajar.

Departemen Agama RI. 2009. Al-Qur'an dan Terjemahnya, Bandung: PT Sygma Examedia Arkanlema.

Dimyati. 2017. Paradigma baru ekonomi Islam, La_Riba Jurnal Ekonomi Islam, Vol 1. 2 Desember.

Diah. 2010. Pengaruh Pengembangan Sumber Daya Manusia Terhadap Produktivitas Kerja Karyawan Pada PT. Cakra Guna Cipta Malang, Jurnal Modernisasi, vol. 6, No. 1 February.

Fadlan. 2010. Konsep Pembangunan Ekonomi Berbasis Islam, Al-Ahkam Vol. V, No.2 Desember.

Fatoni, Abdurrahmat. 2006. Manajemen Sumber Daya Manusia, Jakarta: rneka Cipta.

Ghozali, Mohammad. 2018. Kewirausahaan Syariah, Ponorogo: Unida Gontor Press.

Haluty, Djaelany. 2014. Islam dan Manajemen Sumber Daya Manusia Yang Berkualitas, Jurnal Irfani, Volume. 10 Nomor 1, Juni.

Hartono, Jogiyanto. 2016. Metodelogi Penelitian Bisnis, Fakultas Ekonomika dan Bisnis UGM, Yogyakarta.

Huda, Nurul, dkk. 2015. Ekonomi Pembangunan Islam, Jakarta: Prenada Media Group. 
Kurniawan, Sugeng. 2015. Konsep Manajemen Pendidikan Islam Perspektif Al-Qur'an Dan Al-Hadits, Nur El-Islam, volume 2 Nomor 2 Oktober.

Moekijat. 1989. Perencanaan Sumber Daya Manusia, Bandung: Mandar Maju. 1991. Latihan dan Pengembangan Sumber Daya Manusia, Bandung: Mandar Maju.

Nawawi, Hadari. 1997. Administrasi Pendidikan, Jakarta: Gunung Agung.

Purwana, Agung, Eko. 2013. Pembangunan Dalam Perspektif Ekonomi Islam, Justitia Islamica, Vol. 10/no. 1/Jan-Juni.

Raco. 2010. Metode Penelitian Kualitatif, Jakarta: PT Gramedia.

Rasyid, Muhammad, Makmun. 2016. Islam Rahmatan Lil Alamin Perspektif Kh. Hasyim Muzadi, Epistemé, vol. 1l, No. 1, Juni.

Rachmawati, Imami, Nur. 2007. Pengumpulan Data Dalam Penelitian Kualitatif: Wawancara, Jurnal Keperawatan Indonesia, volume ll, No.l, Maret.

Siregar, Ratonggi. 2017. Sumber Daya Manusia Dalam Pembangunan Nasional, Prosiding Seminar Nasional Tahunan Fakultas Ilmu Sosial Universitas Negeri Medan.

Sugiyono. 2014. Metode Penelitian Bisnis, Bandung: Alfabeta.

Suryana. 2010. Metodelogi Penelitian, Bandung: Universitas Pendidikan Indonesia.
Susarni. 2016. Pengaruh Pemberdayaan Sumber Daya Manusia Terhada Kinerja Pegawai Negeri Sipil Pada Kantor Sekretariat Daerah Kabupaten Muna Barat, (Kendari: Fakultas Ekonomi dan Bisnis, Universitas Halu Oleo)

Sutrisno, Edy. 2009. Manajemen Sumber Daya Manusia, Jakarta: Kencana.

Syamsuri. 2016. Paradigma pembangunan ekonomi; Satu analisis tinjauan ulang dari perspektif ekonomi Islam, Islamic economic: Jurnal Ekonomi Islam, vol. 7 No. 2 Juli- Desember. 2016. Eksistensi dan Kontribusi Pondok Modern Darussalam Gontor Dalam Pembangunan Sumber Daya Manusia, Jurnal Ta'dib, vol. 1l, No. 2, Desember.

2018. Ekonomi Pembangunan Islam, Ponorogo: Unida Gontor Press.

Steffenny. 2013. Analisis Penerapan Human Resource Training and Development Efektivitasnya Pada Pt. Jaya Mas Mandiri plus Surabaya, Agora, vol. 1, No. 3.

Rayadi. 2012. Faktor Sumber Daya Manusia Yang Meningkatkan Kinerja Karyawan dan Perusahaan Di Kalbar, Jurnal Eksos, volume 8, no. 2, June.

Sujarweni, Wiratna. 2014. Metodelogi Penelitian, Yogyakarta: Pustaka Baru Press.

Tamkin, Borhan, Joni. 2008. Pemikiran pembangunan ekonomi berteraskan Islam, Jurnal Ushuluddin.

Wildanur. 2013. Analisis Beban Kerja Sumber Daya Manusia dalam 
Aktivitas Produksi Komoditi Sayuran Selada (Studi Kasus: CV Spirit Wira Utama), Jurnal Manajemen dan Organisasi Vol. IV, No. 2, August.

Yusuf, Burhanuddin. 2016. Manajemen Sumber Daya Manusia di Lembaga Keuangan Syariah, Jakarta: Rajawali Pers.

\section{Magazine}

Jalan Para Da'i, Majalah YDSF, Edisi 360, Maret 2018, Jumadil Akhir - Rajab 1439

Tahun-Tahun yang Menentukan, Majalah Al-Falah, Edisi 30 Tahun YDSF

\section{Internet}

www.BPS.go.id

YDSF,Surabaya,(Profil), http://www .ydsf.org/tentang-kami 